DOI: $10.20472 / E S .2020 .9 .1 .004$

\title{
SYMMETRIC BEHAVIOUR TO FULFIL THE MAIN OBJECTIVE AS THE BASIS FOR THE CREDIBILITY OF CENTRAL BANKS BEHAVIOUR ON THE EXAMPLE OF CNB
}

\section{ANDREA ČEČRDLOVÁ}

\begin{abstract}
:
The aim of the paper is to verify whether the CNB behaved symmetrically in the period of 1998-2016 while fulfilling its basic mandate - price stability - and whether the decision to use the exchange rate commitment influenced the assessment of its symmetrical approach. The paper provides a comprehensive view of the CNB's symmetry, which is considered as the basis for the credibility of central bank behaviour in achieving the main objective - price stability. Based on analyses of deviations of inflation from the target in both directions and assess the implemented exceptions, it was shown that the CNB was stricter than was necessary from the point of view of resulting inflation over the period under review. In most of the years, it was below the inflation target which can be judged as an asymmetric approach in monetary policy decisions. The decision to apply the exchange rate commitment has had an impact on the CNB's symmetric approach. From the point of view of mere symmetry, the introduction of the exchange rate commitment was a positive step.
\end{abstract}

\section{Keywords:}

CNB, central bank, monetary policy, inflation target, inflation, symmetry, credibility

JEL Classification: E31, E52, E58

\section{Authors:}

ANDREA ČEČRDLOVÁ, University of Economics, Prague, Czech Republic, Email: a.cecrdlova@gmail.com

\section{Citation:}

ANDREA ČEČRDLOVÁ (2020). Symmetric Behaviour to Fulfil the Main Objective as the Basis for the Credibility of Central Banks Behaviour on the Example of CNB . International Journal of Economic Sciences, Vol. IX(1), pp. 68-82., 10.20472/ES.2020.9.1.004 


\section{Introduction}

The credibility of central banks (CBs) is very important for fulfilling their basic (and not only basic) goals, as they cannot influence inflation expectations without trust, and therefore need to use more, or even stronger, monetary-policy instruments to achieve the goal. This was the thesis universally recognized by the world academic community before the emergence of the last crisis. Symmetrical behaviour to achieve the goal over a longer horizon can be considered as the basis for the credibility of central bank behaviour in meeting the main objective of price stability.

The aim is therefore to answer the hypothesis whether the Czech National Bank (CNB) behaved symmetrically in fulfilling its basic mandate in the period of 1998-2016 and whether the decision of use the exchange rate commitment in November 2013 affected the assessment of the symmetric approach.

\section{Theoretical basis}

The status of CBs in democratic states is generally enshrined in the law. In the case of the CNB, this is a legal regulation in the Constitution itself, specifically in Act No. 6/1993 Coll., About the CNB, and other subsequent regulations, e.g. Bank Act, etc. (CNB, 2017a).

Independence of $\mathrm{CB}$ is a key condition for a successful implementation of monetary policy (MP) and, in the case of the Czech Republic, sustainable non-inflationary growth of the economy. Therefore, the CNB enjoys a high degree of independence from political structures in fulfilling its statutory functions from the outset.

Regardless of any monetary policy regime under which CB operates, its primary objective is clear, ensuring price stability.

Since 1998, the CNB has been operating in the inflation targeting regime. An important feature of this regime is not only the public explicit declaration of the inflation target (IT), or the succession of goals, but also the use of the inflation forecast and the medium-term strategy. The CNB always uses the most recent forecasts to change the MP instruments to offset excessive inflationary or disinflationary pressures that diverge future inflation from the set IT. 


\section{Trust in the CNB}

CB Communication plays an important role in the inflation targeting regime. The cornerstone of this communication is the Reports about Inflation, which are published regularly every quarter. Each such report contains a description of the new macroeconomic forecast and the assessment of past monetary and economic development. The purpose of regular publishing of Reports about Inflation is the CNB's effort to make its activity transparent, understandable, predictable and consequently credible. As Jens Wiedmann said "announcing an inflation target plays a key role, as this leads to stability gains (Erceg, Levin, 2003). It helps to anchor economic agents' inflation expectations, which pays off in the form lower inflation volatility, amongst other things." (Weidmann, 2018a, p. 3)

The basic conviction of the CNB is the confidence of financial markets, credit rating agencies and the public, as only a credible monetary policy can effectively influence inflation expectations and thus minimize costs in securing the main goal of maintaining price stability.

In mid-2017, the IMF published the article The Czech Miracle: Inflation Targeting in the CNB, which describes the CNB's experience of inflation targeting since its introduction in 1998 to the present, with its emphasis on its transparent communication to the public. As the authors themselves write, the CNB's experience is a successful example of building confidence in monetary policy and can serve as a useful model for other central banks (Clinton et al., 2017). Co-author of the text Tibor Hlédik from the CNB's Changing Section further comments that the spell is that the CNB provides a set of information that most central banks still do not provide (Hlédik, 2017). It is also important to mention that since the end of the 1990s the part of the CNB has been a number of great economists who have contributed to the development of prognostic models; it is also important not to neglect the support of past banking councils, the way of cooperation between sectoral and model experts, thanks to it is possible use all of the knowledge and integrate them into an integrated version of the forecast that makes issues to most CBs. Thanks to this, the Czech Republic can be proud of the low inflationary values typical for Western countries. The advantage of rapid disinflation, which was initially criticized by most CBs, was subsequently reflected in low interest rates which were the reason why the Czech Republic was not suffering from a shortage of foreign loans, as was the case in Hungary and Slovakia.

The specificity of transparent communication with public in the case of the CNB means, that $C B$ should not be only a passive but also an active player in the economy. The CNB interprets not only the current situation but also presents to the public future interest rate and exchange rate developments (see regular disclosure of detailed forecasts).

The Dincer and Eichengreen paper (2014) offers a picture of how the CNB's transparency index was developing in the period from 1998 to 2010, which according to the IMF the CNB has reached almost the maximum values in 2015 due to the deepening of published forecasts (more 
detailed breakdowns) and the introduction of a number of institutional steps in order to inform the public in a better way ${ }^{1}$ (Hlédik, 2017).

In 2015, the CNB also won the prestigious Central Banking Transparency Award. This award was granted by the Central Banking Publications to the CNB for the openness and use of new instruments in communication (Central Banking, 2015).

A strong emphasis on a high level of transparency is particularly due to the communication of the expected interest rate development, which has an effect on the financial market yield curve, due to which the CNB can influence and, in the vast majority of its operations, influence the inflation expectations of economic operators.

$\mathrm{CB}$ communication with the public therefore plays an important role, but it is not enough just to publish forecasts and expected interest rate developments. The comments of individual Bank Board members on the trajectory indicated by the forecast are also carefully monitored.

(Borio, Zabai, 2016) However, the use of unconventional monetary policy instruments such as quantitative easing or exchange rate interventions cannot be omitted. According to the paper of Claudia Boria and Anny Zabai, these so-called unconventional monetary policy instruments adopted by the arrival of the financial crisis (2012-2015) have become commonly used instruments over the past few years.

(Borio, Zabai, 2016) This paper highlights the combination of unconventional monetary policy and declining yields. Indeed, the revenue/cost ratio changes over time to the benefit of costs. Not to mention issues related to exits from these politics. The authors of this study draw attention to the fact that while the benefit may seem sufficient in the short term, in longer periods may be more likely to be damaging. By using these tools, CBs also diminish their room for maneuver and, as a result, the ability to cope with the recession that is inevitable in time. The overall pressure to use more experimental measures, in the best case unpredictable, in the worst dangerous, may become too strong at any point. Overall, the credibility and legitimacy of CBs can be questioned.

„Today, ten years after the financial crisis escalated, policy rates are still at historic lows.“ (Weidmann, 2018b, p. 2) In the case of EU „the Eurosystem has accumulated a huge portfolio of securities of various kinds, and refinancing operations offered to banks have remained more than generous. As a result, excess liquidity stands at a level nine times higher than after the Lehman collapse, and monetary policy is roughly as expansionary as it was when the crisis was raging. Put differently, the remaining policy space is rather limited. "(Weidmann, 2018b, p. 2)

\footnotetext{
1 See the Governor's press conference after Bank Board meetings, CNB Bank Board voting, and regular communication with analytics, enabling communication to be targeted effectively based on target audiences.
} 


\section{CNB forecasts and reality}

Forecasts form a very important element in the inflation targeting regime. Given monetary policy outlook, its decision-making is based largely on inflation forecasts and other macroeconomic variables. Thus, high-quality forecasts can contribute to the fulfilment of monetary policy objectives.

The quality of forecasts or prediction models can be evaluated in different ways. For example, it is possible to focus on general methodological aspects, verifying the calibration of prediction models, optimal combination of forecasts from different models, or statistical evaluation of model prediction capabilities (Pagan, 2003).

Thanks to forecasts from previous years (2005-2016), it is possible to see how the CNB's forecasts are consistent with the resulting inflation. ${ }^{2}$ In the Rol, forecasts are out-of-the-box in the period under review. Even without complex calculations, there can be visually noticed a significant deviation of forecasts from the resulting inflation.

In 2005, there was a significant deviation of the forecast from the resulting inflation as a result of postponement of changes in indirect taxes, markedly higher growth in regulated prices, particularly in the health, postal and telecommunication sector, and fuel prices. Influence of foreign factors, such as lower foreign demand or interest rates, which were highly antiinflationary, were also noticeable.

In 2006, the resulting inflation was broadly in line with the forecast except for the fourth quarter, when the CNB did not expect such a strong appreciation of the domestic currency, and so high growth of regulated prices. As a result, there was a significant deviation in this quarter.

The 2007-2009 period was influenced mainly by the global financial crisis that caused the global downturn in real economies. In this period, the resulting inflation compared to forecasts was delayed in particular by the impact of indirect taxes, which the CNB standardly excludes, as well as by the effect of regulated prices, see reform measures in the health sector in 2008 and prices of fuel and energy.

From 2010, with the transition to a new $2 \%$ inflation target, some improvements can be seen in the forecasts. During 2010-2012, the resulting inflation was developing more or less according to the CNB's forecasts.

From 2013, it is possible to see again the mismatch between forecasts and resulting inflation. In particular, during this period, it is possible to see too high expectations of the CNB in connection with the exchange rate commitment, which was expected to quickly bring inflation

\footnotetext{
2 Forecasting refers to the period from 2005 due to the transition to a point target for headline inflation. From this year on, it is also possible to carry out a more thorough analysis of the CNB's measures thanks to the larger amount of data available.
} 
near the inflation target. ${ }^{3}$ Given that the fall in inflation was affecting not only the Czech Republic but also other EU countries, it was difficult for the Czech Republic, a small open economy, to cope with these anti-inflationary pressures. At that time, the CNB was no longer able to use its basic monetary policy instrument because the basic interest rates were at technical zero, thanks to a multiple cut in interest rates during 2012 (see figure 1).

Figure 1: Development of the CNB key interest rates and headline inflation in 2005-2016

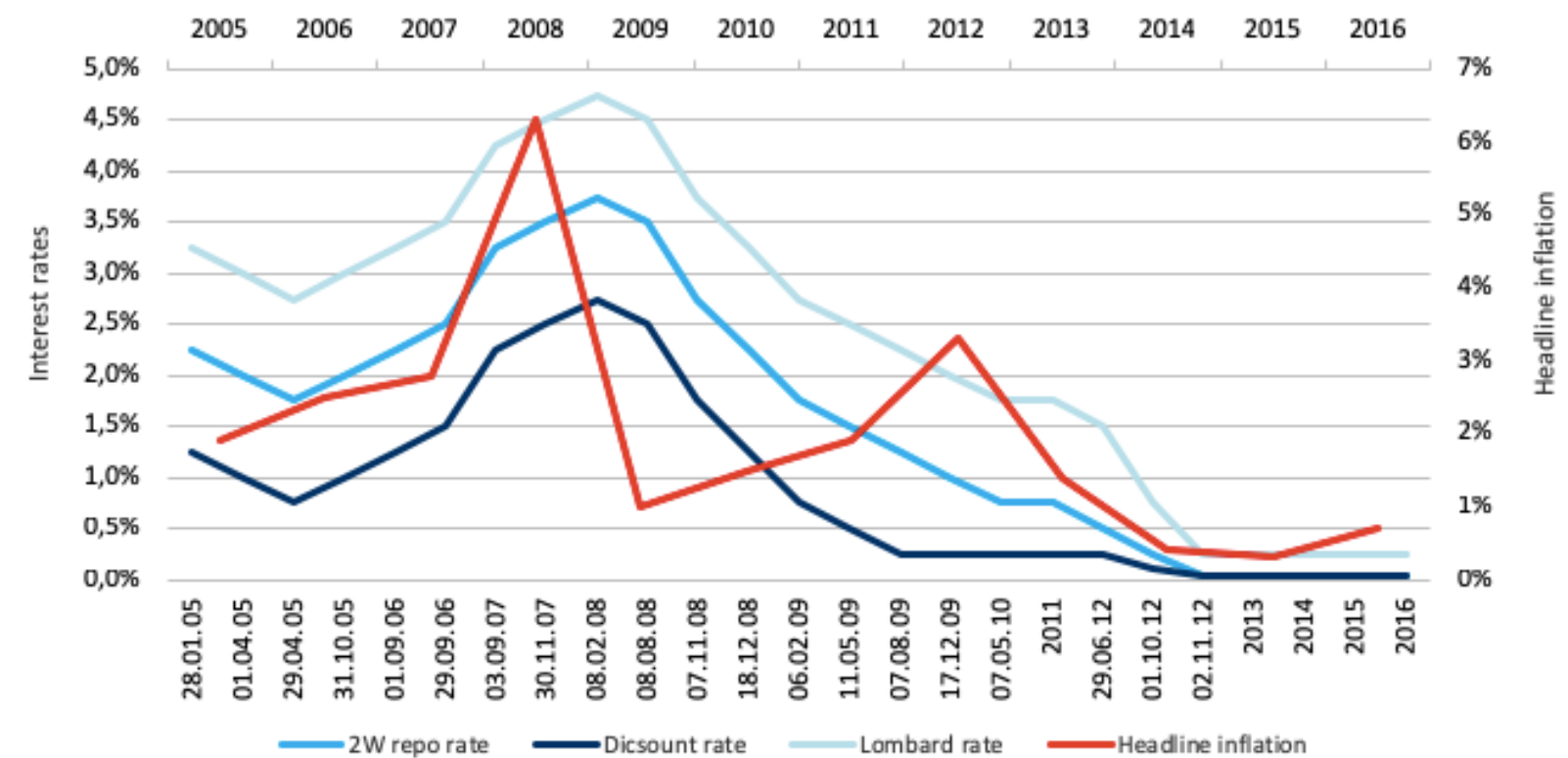

Source: CNB (2017b), own processing

One should not forget that the Government's measure to consolidate public finances at that time negated the CNB's efforts to liberalize monetary conditions, as tax hikes hampered domestic demand, helping to deepen the cyclical downturn in the economy. The question here is whether the reduction in interest rates to technical zero was the right decision in relation to the fiscal and monetary policy mismatch that prevailed during 2012.

The mismatch between forecasts and resulting inflation was noticeable until the end of the reference period, 2016. Regulated prices had a major influence here, which in this period (especially 2014-2015) led to significant downward pressure on inflation.

The most prominent item in 2014 was the telecoms item where the introduction of unrestricted mobile tariffs in 2013 was still projected (see figure 2). The impact of energy prices was also evident, with the projected fall in electricity and gas prices. It is also worth mentioning the

\footnotetext{
${ }^{3}$ Monetary policy using the interest rate policy instrument affects the fulfilment of the inflation target at the 12-18 months horizon. However, in the exchange rate regime, monetary policy is beginning to translate into inflation with a significantly shorter delay. It is about half the time, ie 6-12 months.
} 
decrease in the health item, which was mainly due to the cancellation of hospital stay fee of CZK 100 (CEVRO, 2014).

\section{Figure 2: CPI by COICOP ${ }^{4}$ for 2014 - Inflation rate}

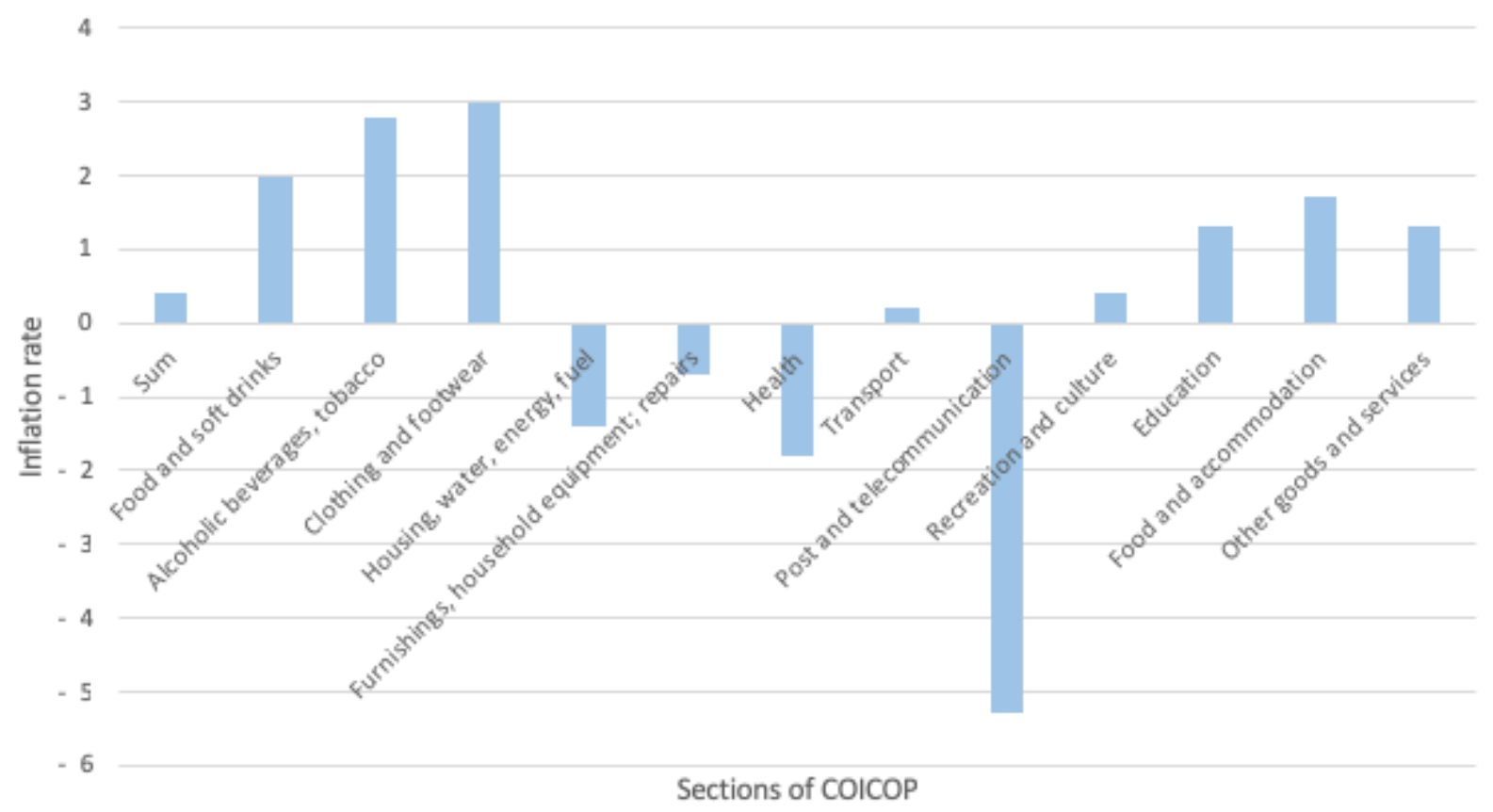

Source: CZSO, own processing

As Pavel Řežábek, the then member of the CNB Bank Board, commented, if we look specifically at which prices fell the most, it is electricity and gas with an impact on inflation of -0.8 percentage points. They pull inflation down. If they were not, inflation would above one percent and there would be no drama (Zavadilová, 2014). In total with health and telecommunications, the effect of regulated prices on inflation was indeed significant, as it exceeded 1 p. p. (see table 1).

\footnotetext{
4 The Classification of Individual Consumption Acoording to Purpose, abbreviated as COICOP, is the international reference classification of household expenditure by the United Nations Statistics Division (2018). "The objective of COICOP is to provide a framework of homogeneous categories of goods and services“ (United Nations Statistics Division, 2018).
} 
Table 1: Structure of the growth of regulated prices in 2013 and 2014

\begin{tabular}{|c|c|c|c|c|}
\hline & \multicolumn{2}{|c|}{ YEAR-ON-YEAR (in \%) } & \multicolumn{2}{|c|}{$\begin{array}{c}\text { CONTRIBUTIONS } \\
\text { (influence on year-on-year } \\
\text { inflation in p. p.) }\end{array}$} \\
\hline & 2013 & JAN 2014 & 2013 & JAN 2014 \\
\hline REGULATED PRICES & 2.2 & -4.1 & 0.40 & -0.71 \\
\hline Electricity & 3.2 & -10.4 & 0.15 & -0.50 \\
\hline Gas for Households & -3.5 & -9.1 & -0.10 & -0.29 \\
\hline Heat & 4.3 & 1.1 & 0.09 & 0.02 \\
\hline Water & 6.7 & 3.4 & 0.07 & 0.03 \\
\hline Garbage Collection & 11.0 & -0.5 & 0.05 & 0.00 \\
\hline Sewer rates & 7.2 & 3.1 & 0.03 & 0.02 \\
\hline Propan butan & 0.1 & -1.9 & 0.00 & 0.00 \\
\hline Health & 2.6 & -8.0 & 0.05 & -0.09 \\
\hline Transport & 1.4 & 1.2 & 0.03 & 0.02 \\
\hline Telecommunication & 8.2 & NA & 0.01 & NA \\
\hline Education & 1.4 & 0.6 & 0.00 & 0.00 \\
\hline Eating Fare & 2.3 & 1.8 & 0.02 & 0.02 \\
\hline Others & 3.9 & 2.6 & 0.03 & 0.02 \\
\hline
\end{tabular}

Source: CNB (2014a, 2014b), own processing

In 2015 (see figure 3), the regulated part of the basket had a significant impact on headline inflation, in particular in the form of the abolition of regulatory fees in the health sector (with effect from 1.1.2015), which caused a significant price slump in this regulated part of the consumer basket (STAN, 2015). 


\section{Figure 3: CPI by COICOP for 2015 - Inflation rate}

6

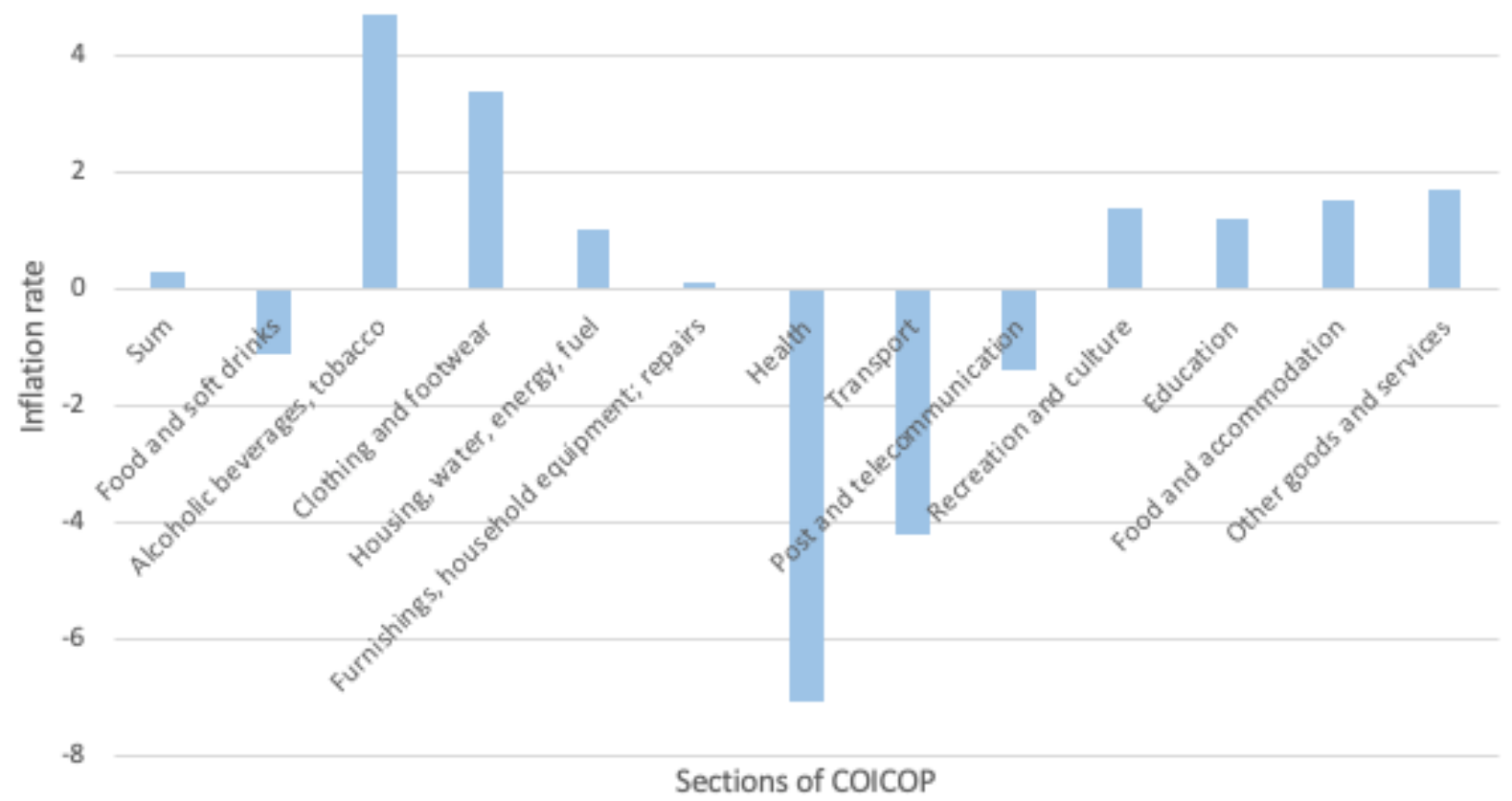

Source: CZSO, own processing

In summary, the CNB's forecasts in most of the years in the monitored period were not trendily able to hit (8:4) the evolution of resulting inflation (CNB, 1998-2017) ${ }^{5}$.

\section{Symmetry of the CNB}

Inflation forecasts include a relatively large impact of changes to indirect taxes. In practice, since the July 2003 forecast, when the tax impact was significant for the first time, the primary impact of the headline inflation is subtracted and the CNB responds to the deviation of the inflation so adjusted (inflation excluding the primary impact of changes in indirect taxes), by other words, the CNB is oriented towards meeting the inflation target for this inflation (CNB, 2007).

In assessing the exceptions to meeting the inflation target, it is also necessary to be aware that the CNB does not consider the influence of the regulated part of the consumer basket within the framework of monetary policy (CNB, 2007). It is important to note that the influence of regulated prices may often have larger impact than changes of indirect taxes.

Here it is possible to refer to the crisis years 2014 and 2015, when the influence of just regulated prices, which significantly pushed the headline inflation down, was observable. In connection with this, it is necessary to ask why the CNB does not exclude the influence of regulated prices.

\footnotetext{
5 The exact justification for these deviations is not discussed in this paper because it is a topic for a separate article and the CNB does not publish detailed analysis like that.
} 


\subsection{Exceptions to meeting the inflation target}

The CNB used the exceptions only in the context of changes in indirect taxes in the monitored period of inflation targeting. The most significant changes occurred in 2008, 2010 and 2012, when the impact of indirect taxes on headline inflation was clearly the largest and exceeded the level of 1 p. p (see table 2). In connection with this, it is necessary to ask why the CNB only excludes tax changes upwards within the influence of indirect taxes.

\section{Table 2: Influence of indirect taxes on real inflation ${ }^{6}$}

(monitored period 2005-2016) ${ }^{7}$

\begin{tabular}{|c|c|c|c|}
\hline YEAR & $\begin{array}{c}\text { REAL HEADLINE } \\
\text { INFLATION (\%) }\end{array}$ & $\begin{array}{c}\text { MONETARY POLICY- } \\
\text { RELEVANT INFLATION (\%) }\end{array}$ & $\begin{array}{c}\text { IMPACT OF INDIRECT } \\
\text { TAXES (\%) }\end{array}$ \\
\hline 2003 & 0.1 & $\mathrm{X}$ & $\mathrm{X}$ \\
\hline 2004 & 2.8 & $\mathrm{X}$ & -0.07 \\
\hline 2005 & 1.9 & 1.83 & -0.24 \\
\hline 2006 & 2.5 & 2.26 & -0.62 \\
\hline 2007 & 2.8 & 2.18 & $\mathbf{1 . 9 4}$ \\
\hline 2008 & 6.3 & 4.36 & -0.12 \\
\hline 2009 & 1.0 & 0.88 & -1.12 \\
\hline 2010 & 1.5 & 0.38 & -0.04 \\
\hline 2011 & 1.9 & 1.86 & $\mathbf{1 . 2 2}$ \\
\hline 2012 & 3.3 & 2.08 & -0.78 \\
\hline 2013 & 1.4 & 0.62 & -0.17 \\
\hline 2014 & 0.4 & 0.23 & -0.15 \\
\hline 2015 & 0.3 & 0.15 & -0.22 \\
\hline 2016 & 0.7 & 0.48 & -0.29 \\
\hline OVERALL EXCEPTION (\%) & & & \\
\hline
\end{tabular}

Source: CNB (1998-2017), CZSO (2017), own processing

In real terms, the total impact of indirect taxes is $-0.29 \mathrm{pp}$. As a result, the use of monetary policy-relevant inflation within the overall assessment of the CNB`s symmetry is negligible.

\subsection{Total deviation from meeting the inflation target}

\footnotetext{
${ }^{6}$ The plus sign (+) approaches the inflation target, the minus sign (-) moves away from the inflation target.

${ }^{7}$ Monetary policy-relevant inflation figures are not publicly available for 2003-2004.

${ }^{8}$ Monetary policy-relevant inflation is inflation to which monetary policy reacts. It is defined as headline inflation adjusted for first-round effects of changes to indirect taxes (CNB, 2017c).

${ }^{9}$ With regard to the inflation target.
} 
The greatest deviations can be observed at the beginning and end of the monitored period. The first years are linked to the transition to the floating exchange rate and inflation targeting, while the recent years were significantly affected by the foreign price drop, which was strongly reflected in the development of domestic price level.

\section{Table 3: Deviations from the set inflation target in 1998-2016}

(1998-2001 inflation targets in net inflation, 2002-2016 inflation targets in headline inflation)

\begin{tabular}{|c|c|c|c|c|c|}
\hline YEAR $^{10}$ & $\begin{array}{l}\text { INFLATION } \\
\text { TARGET (\%) }\end{array}$ & $\begin{array}{l}\text { TOLERANCE } \\
\text { BAND }\end{array}$ & ACTUALITY'11 (\%) & $\begin{array}{l}\text { DEVIATION FROM } \\
\text { INF. TARGET (\%) }\end{array}$ & $\begin{array}{l}\text { DEVIATION FROM } \\
\text { TOL. BAND (\%) }\end{array}$ \\
\hline 1998 & 6 & +/- 0.5 p. p. & 5.6 & -0.4 & 0 \\
\hline 1999 & 4.5 & +/- 0.5 p. p. & 0 & -4.5 & -4.0 \\
\hline 2000 & 4.5 & +/- 1 p. p. & 2.6 & -1.9 & -0.9 \\
\hline 2001 & 3 & +/- 1 p. p. & 3.3 & 0.3 & 0 \\
\hline 2002 & 3.75 & +/- 1 p. p. & 1.8 & -1.95 & -0.95 \\
\hline 2003 & 3.5 & +/- 1 p. p. & 0.1 & -3.4 & -2.4 \\
\hline 2004 & 3.25 & +/- 1 p. p. & 2.8 & -0.45 & 0 \\
\hline 2005 & 3 & +/- 1 p. p. & 1.9 & -1.1 & -0.1 \\
\hline 2006 & 3 & +/- 1 p.p. & 2.5 & -0.5 & 0 \\
\hline 2007 & 3 & +/- 1 p. p. & 2.8 & -0.2 & 0 \\
\hline 2008 & 3 & +/- 1 p.p. & 6.3 & 3.3 & 2.3 \\
\hline 2009 & 3 & +/- 1 p.p. & 1.0 & -2.0 & -1.0 \\
\hline 2010 & 2 & +/- 1 p.p. & 1.5 & -0.5 & 0 \\
\hline 2011 & 2 & +/- 1 p.p. & 1.9 & -0.1 & 0 \\
\hline 2012 & 2 & +/- 1 p.p. & 3.3 & 1.3 & 0.3 \\
\hline 2013 & 2 & +/- 1 p. p. & 1.4 & -0.6 & 0 \\
\hline 2014 & 2 & +/- 1 p. p. & 0.4 & -1.6 & -0.6 \\
\hline 2015 & 2 & +/- 1 p. p. & 0.3 & -1.7 & -0.7 \\
\hline 2016 & 2 & +/- 1 p.p. & 0.7 & -1.3 & -0.3 \\
\hline \multicolumn{4}{|c|}{ OVERALL DEVIATION IN ABSOLUTE VALUE (\%) } & 26.5 & 13.55 \\
\hline \multicolumn{4}{|c|}{ AVERAGE DEVIATION IN ABSOLUTE VALUE (\%) } & 1.39 & 0.71 \\
\hline \multicolumn{4}{|c|}{ OVERALL DEVIATION (\%) } & -17.3 & -8.35 \\
\hline \multicolumn{4}{|c|}{ AVERAGE DEVIATION (\%) } & -0.91 & -0.44 \\
\hline
\end{tabular}

Source: CNB (1998-2017), CZSO (2017), own processing

When referring to the inflation target set for 2005 in the headline inflation, the average deviation from the inflation target over the reference period (19 years) is approx. $1.39 \%$ (- $0.91 \%)$, from the tolerance band $0.71 \%(-0.44 \%)$. Considering, that the value of the tolerance band was +/-

\footnotetext{
10 In the period 2002-2005, the centre of target band was chosen as the inflation target.

${ }^{11}$ Net inflation rate in \%, y/y, average for 1998-2001; headline inflation rate in \%, y/y, average for 2002-2016.
} 
1 p. p. in the reference period, the average deviation from the inflation target is significant (see table 3).

The sum of deviations for individual years shows the fact that in the inflation targeting period a certain consistency can be seen in the asymmetry of deviations, inflation is in most of the years below the target. For the CNB, it is more typical to undershoot the inflation target than its overshooting, as evidenced by a negative deviation over the period under review. The only exception was the year 2008 when regulatory fees in the health sector and the reform of Czech public finances (changes in indirect taxes) were introduced and 2012 when the increased VAT rate was applied and the higher than expected increase in regulated prices appeared, especially natural gas prices and regulated rent prices. The year 2001 was also an exception, however, it is indicated in net inflation, which was affected mainly by the price development of food, beverages and tobacco.

\section{Conclusion}

The assessment of the exceptions to meeting the inflation target is complicated as the CNB only considering indirect tax effects while the influence of regulated prices is not considered, although it may often have a greater impact than the change of indirect taxes.

Here, reference can be made to the crisis years 2014 and 2015, when regulated prices have significantly pushed down headline inflation.

For the monitored period 1998-2016, the average deviation from the inflation target (calculated in absolute value) is approx. $1.39 \%$, from the tolerance band $0.71 \%$. Considering that the value of the tolerance band in the reference period was $+/-1$ p. p., the average deviation is significant. The sum of deviations of the resulting inflation from the set inflation target for individual years in the reference period 1998-2016 points to the fact that in the inflation targeting period a certain degree of consistency can be seen in the asymmetry of the deviations which in most of the years aim downwards. In conclusion, the undershooting of inflation target is typical for the CNB, as evidenced by the overall negative deviation.

According to the analysis, it can be judged that the CNB was stricter within the monetary policy than was necessary from the viewpoint of the resulting inflation. In connection with the fact that, in most of the years under review, the CNB was below the inflation target, it can also be judged to be asymmetric in the decision-making process within the monetary policy.

The CNB used exceptions in the inflation targeting period (2003-2016) only in the context of changes in indirect taxes. The most significant changes occurred in 2008, 2010 and 2012, when the impact of indirect taxes on resulting inflation exceeded the level of 1 p. p. In connection with this, it is necessary to ask two questions: Why did the CNB always excepted the influence of indirect taxes, not the influence of regulated prices, and why the CNB excepts the impact of indirect taxes only if the tax changes go upwards. 
In sum, the total effect of indirect taxes was -0.29 p. p., resulting in negligible significance for the use of monetary policy-relevant inflation to assess the CNB's symmetry. If the monetary policy-relevant inflation meant to be taken as authoritative, the assessment of asymmetry towards tighter monetary policy-relevant inflation would be intensified because of the negative result -0.29 p. p.

In summary, the decision to use the exchange rate commitment had an impact on the assessment of the CNB's symmetric approach. It was an unconventional monetary policy instrument, the use of which is intended mainly for a short period in connection with declining efficiency, but not for long, as was the case with the Czech Republic. Given that the assessment of resulting inflation concluded that the CNB was stricter than necessary, the introduction of an exchange rate commitment meant that the monetary conditions were eased. Therefore, from the point of view of symmetry, the introduction of the exchange rate commitment was a positive step.

With the introduction of the exchange rate commitment as a result of the cuts in key interest rates to technical zero, the question arises as to whether this reduction was the right decision in the context of the fiscal and monetary policy mismatch that was at that time. At that time, the government's measures to consolidate public finances partly negated the CNB's effort to ease monetary conditions, as tax growth slowed down domestic demand, which helped deepen the cyclical downturn in the economy. By gradually lowering its key interest rates, the CNB exhausted its basic monetary policy instrument and could not effectively influence inflation in the coming years.

To conclude, the measures during the last crisis were different from those of previous crises. Non-traditional monetary policy instruments were used. The more pronounced negative effects of these measures can deepen the debate on limiting the excessive independence of monetary authorities, and hence central banks.

The paper was carried out with the financial support of the Grant Agency of the University of Economics (VSE IGS F5/2/2018). 


\section{Reference}

BORIO, C., ZABAI, A. (2016). Unconventional Monetary Policies: a Re-appraisal. BIS Working Papers, No. 570, p. 49. [online] Available at: https://www.bis.org/publ/work570.pdf [Accessed 15 Aug. 2019].

CENTRAL BANKING (2015). The Winners of the Central Banking Awards 2015. [online] Available at: https://www.centralbanking.com/central-banking/news/2389654/thewinners-of-the-central-banking-awards-2015 [Accessed 15 Aug. 2019].

CEVRO (2014). Fees in Health care. [online] Available at: http://www.cevro.cz/web files/soubory/ctrnacni-deniky/2014/14denik 06 2014.pdf [Accessed 15 Aug. 2019].

ClinTON, K., HLÉDIK, T., HOLUB, T., LAXTON, D., WANG, H. (2017). Czech Magic: Implementing Inflation-Forecast Targeting at the CNB. [online] Available at: https://www.imf.org/en/Publications/WP/Issues/2017/01/30/Czech-Magic-ImplementingInflation-Forecast-Targeting-at-the-CNB-44604 [Accessed 15 Aug. 2019].

CNB (2017a). About CNB. [online] Available at: http://www.cnb.cz/cs/o cnb/ [Accessed 15 Aug. 2019].

CNB (2007). Applying Exceptions to meeting the Inflation Target for Indirect Tax Adjustments. [online] Available at: https://www.cnb.cz/cs/menova-politika/zpravy-o-inflaci/tematickeprilohy-a-boxy/Uplatnovani-vyjimek-z-plneni-inflacniho-cile-na-upravy-neprimych-dani/ [Accessed 15 Aug. 2019].

CNB (2017b). Monetary Policy Instruments. [online] Available at: https://www.cnb.cz/cs/menova-politika/mp-nastroje/ [Accessed 15 Aug. 2019].

CNB (1998-2017). Monetary Policy Publications - Reports about Inflation. [online] Available at: https://www.cnb.cz/cs/menova-politika/zpravy-o-inflaci/ [Accessed 15 Aug. 2019]

CNB (2014a). Report about Inflation - I/2014. [online] Available at: https://www.cnb.cz/cs/menova-politika/zpravy-o-inflaci/Zprava-o-inflaci-I-2014/ [Accessed 15 Aug. 2019].

CNB (2014b). Report about Inflation - II/2014. [online] Available at:

https://www.cnb.cz/cs/menova-politika/zpravy-o-inflaci/Zprava-o-inflaci-II-2014/ [Accessed 15 Aug. 2019].

CNB (2017c). What the monetary policy-relevant inflation is? [online] Available at: https://www.cnb.cz/cs/casto-kladene-dotazy/Co-to-je-menovepoliticka-inflace/ [Accessed 15 Aug. 2019]. 
CZSO. CPI by COICOP - Inflation rate. [online] Available at: https://vdb.czso.cz/vdbvo2/faces/cs/index.jsf?page=vystupobjekt\&pvo=CEN08C1\&z=T\&f=TABULKA\&skupld $=1773 \& k$ atalog $=31779 \& p v o=C E N 08 C$ 1 [Accessed 15 Aug. 2019].

CZSO (2017). Main Macroeconomic Indicators. [online] Available at: https://www.czso.cz/csu/czso/hmu cr [Accessed 15 Aug. 2019].

ERCEG, CH. J., LEVIN, A. T. Imperfect credibility and inflation persistence. [online] Available at:

https://pdfs.semanticscholar.org/9d2d/a3cf0e79d20a8aa756d0a8d42151d9717693.pdf [Accessed 15 Aug. 2019].

HLÉDIK, T. (2017). The CNB is One of the Most Transparent Central Banks in the World. [online] Available at: https://www.cnb.cz/cs/o cnb/vlog-cnb/Tibor-Hledik-CNB-patri-mezinejtransparentnejsi-centralni-banky-na-svete/ [Accessed 15 Aug. 2019].

PAGAN, A. (2003). Report on Modelling and Forecasting at the Bank of England [online]. Available at: https://papers.ssrn.com/sol3/papers.cfm?abstract id=707049 [Accessed 15 Aug. 2019].

STAN (2015). Čížek (STAN): The Abolition of Regulatory Charges Will Reduce the Stability of Health Care. [online] Available at: https://www.parlamentnilisty.cz/politika/politicivolicum/Cizek-STAN-Zruseni-regulacnich-poplatku-snizi-stabilitu-zdravotnictvi-353584 [Accessed 15 Aug. 2019].

UNITED NATIONS STATISTICS DIVISION (2018). Classification of Individual Consumption According to Purpose (COICOP) 2018. [online] Available at: https://unstats.un.org/unsd/classifications/businesstrade/desc/COICOP english/COICOP 2018 - pre-edited white cover version 2018-12-26.pdf [Accessed 15 Aug. 2019].

WEIDMANN, J. (2018a). Central bank communication as an instrument of monetary policy. [online] Available at: https://www.bis.org/review/r180511a.pdf [Accessed 15 Aug. 2019]. WEIDMANN, J. (2018b). From extraordinary to normal - reflections on the future monetary policy toolkit. [online] Available at: https://www.bis.org/review/r181116a.pdf [Accessed 15 Aug. 2019].

ZAVADILOVÁ, T. (2014). Each member of the Bank Board of Directors Is Otherwise Sensitive. CNB. ŘEŽÁBEK, P. [online] Available at: https://www.e15.cz/rozhovory/pavel-rezabekkazdy-clen-bankovni-rady-je-jinak-citlivy-1066220 [Accessed 15 Aug. 2019]. 